\title{
Indisputable reasons for reform of the United Nations
}

\author{
Dzhamal Z. Mutagirov \\ Saint-Petersburg State University, \\ Faculty of Political Science, Department of International Political Processes, \\ Doctor of Philosophical Sciences, Professor.
}

SUMMARY

There are few people now who believe that there is an effectively functioning Center of joint solution of the problems of peace and security in the world. The United Nations, existing three quarters of a century, had not always coped with its mission properly. If the first four decades of its activity the UN really tried to function as a global Institute of peace and security, in the last three decades, negative in its activity have prevailed over positive. In many cases it looked helplessly at the violations of the international law by its members. Some States do no longer reckon with it. Why is this happening and how ought to change the situation? The article shoes the main causes the UN ineffectiveness and proposes some possible ways to its reforming. The Global Institute for peace and security may not be reformed by itself, and not by the 'great powers' only, but by democratically elected representatives of all the nations of the world at an international conference on a base of their true equality. The structure of the governing bodies and their authorities should be defined in accordance with, firstly, the theory of democracy, and secondly, the real challenges of humankind in the twenty-first century.

Keywords: universal Institute for peace and security; nations; societies; States; humankind; democracy; constitutionalism; human and peoples' rights; equality.

\section{INTRODUCTION}

Up to the twentieth century there was no constantly functioning Centre for the prevention of international conflicts in the world. The arising problems were solved usually by the force and a will of the winners at their conferences and congresses, where an awarding of the winners and punishment of the losers took place with imposing on them certain restrictions. It had happened in Westphalia in 1648 after the Thirty years' war, in Vienna after the Napoleonic wars, at Paris (1856), and Berlin (1878) congresses after the Crimean and Russo-Turkish wars. Next steps forward had been taken in The Hague in 1899 and 1907 by adoption of a dozen of the conventions and declarations on the rules of war and peace. Constantly functioning decision-making Institute had been established only after the First World War in the form of the League of Nations. It existed for about 20 years and ceased functioning, fully failed with its tasks.

The successor to the League of Nations, - the United Nations - the purposes and principles of which were formulated in the context of the Second World War by the leaders of the 'Big Three', constantly limping has passed into the eighth decade of its life. Analysts of the world politics and international relations, noting both the UN achievements in some areas of international life, and full inefficiency in others and identifying the reasons for successes and failures, offer recommendations for its improvement according to new requirements (Etzioni, 2004; Fassbinder, 1998; Mutagirov, 2009).

The then UN Secretary-General Ban Ki-Moon at a press conference on the occasion of 70-th anniversary of the General Assembly (GA) on September 16, 2015 said about seriousness of the 
errors of certain UN missions, resulting in the worsening the situation in the countries where they were working. With regard to the reform of the Organization, he said that two main aspects have to be distinguished. The first is the restructuring of the governing bodies of the United Nations, and the second - the reform of the organization by enlargement of the Security Council. These ideas had been developed also in his report on the work of the Organization on the 70-th session of the General Assembly [report 2015].

The former U.N. Secretaries General, having visited Germany, Japan and other countries, promised them to support their candidatures for permanent membership of the Security Council (SC). They forgot that it is not in their competence, their mission is a clear organization of work of the Secretariat and other bodies of the United Nations in accordance with the Charter and new decisions of the GA and the SC, as well as informing the world community about activities of the UN. On the eve of the 70 session of the General Assembly, the exSecretary General Kofi Annan also wrote about a need for increasing of both the permanent and the temporary members of the Security Council (The Guardian, 23. 09.2015).

Generally, the proposals on the UN reform are reduced to, firstly, to increase the number of permanent members of the Security Council to 25 - 30 with granting of such status for Germany, Japan, Brazil, South Africa, Nigeria and other large countries, and secondly, to extend mandates until 3 years or more for some temporary members. The South African President spoke from the rostrum of the 70-th session of the UN General Assembly about unfairness of the membership of the Security Council, when more than the billionth Africa does have in it no permanent member, but the continent with less population (Europe) is presented by three permanent members. "We are no longer a colony, the situation in the world has changed since 1945 year", he said. [the UN News 2015].

Thirdly, there is an offer to suspend the right of the permanent members to veto whenever the issues related to international crime are discussed. We believe it is necessary to refuse "from the veto when we are faced with the most serious crimes, including the crime of genocide," the representative of Poland said from the rostrum of the 70-th session of the UN General Assembly (Eastern European, 2015). The President of Chile also proposed to suspend the right to veto, at least in cases of crimes against humanity" (Latin American, 2015). According to the authors of the proposal, the right to veto in the Security Council creates an impasse when discussing the most important issues of international security. It is also recommended to increase the financing the United Nations activity (Jeffrey Sachs. www/project-syndicate.org). According to the researchers of the international relations, it is necessary the most fundamental reform of the United Nations in strict conformity with its Charter (Fassbinder, 1998; Mutagirov, 2018).

As it is not difficult to notice, the proposals of politicians are confined to the updating of the composition of one or more of the UN organs and to revision of the rules of voting in them by adopting amendments to its Charter. But it has been done repeatedly. So, the General Assembly adopted on December 17, 1963, the amendments to articles 23 and 61 of the Charter of the United Nations, according to which the number of members of the Security Council was increased from 11 to 15 and the number of members of the Economic and Social Council - from 18 to 27 (the amendments entered into force on 31 August 1965). Resolutions of the UN General Assembly on creating an office of the High Commissioners for Refugees (1951) and human rights (1993), and Human Rights Council (March 2006) were adopted in the same way. Having adopted similar decisions by the governing bodies themselves, many new agencies, committees and sub-committees of the UN were established. 


\section{LEGAL AND LOGICAL JUSTIFICATION FOR THE UNITED NATIONS' REFORMING}

The UN Charter stipulates that the reform of the Organization should be done at the General Conference by the will of two-thirds of its participants and ratified in accordance with respective constitutional processes by two thirds of the Member-States, including all the Security Council's permanent members [Charter, art. 109]. It somehow fits the theory of democracy, according to which no institution, formed by community of people or the nations to serve them can reform itself; only its creator itself has the right to do this. Therefore, neither the General Assembly, no the Security Council, but only the international community as the whole has the right to reorganize the versatile Institute for peace and security. Democratically elected representatives of the peoples of the entire world should come together at the constituent conference, define the common goals of humankind at the moment and the best ways of achieving them, elaborate the principles of relations between peoples in the process of these objectives achieving, and in strict accordance with them, develop a draft of the Constitution of the Institute best promoting the solution of the common tasks.

Unfortunately, the practice of substitution of societies and peoples for one of their serving institution in the face of State, as well as the will of the members of societies and citizens of the States for the will of temporary functionaries of the States - 'servants of the people', characteristic for the authoritarian States, repeats at the universal level as well. The opinion of the majority members of the universal civil society substitutes here for such of global institution's functionaries selected by the States. So, the amendments to the Charter of the United Nations, 1963 on expansion of the Security Council had been adopted not by the General Conference but by the Organization itself. Where is the opinion of the world community, which should define the main directions to reforming of the universal institute for peace and security? It contains in the scientists-researchers' publications, but the officials extremely rare read them.

What primarily should be guided the world community by, rethinking the objectives, organizational forms and structure of the universal institute for peace and security at each new stage of history?

Firstly, it ought to proceed from that any international institution must strictly comply both with its name and time requirements. The UN in its present form does not respond none of these requirements. First of all, this is a discrepancy of the Organization's name with the real composition of its members. The world community consists of peoples, ethnicities, nations; only the most larger of them have their statehood. Thus, the United Nations in its current form is an organization only of the recognized States (Mutagirov, 2018). This discrepancy, in turn, leads to a serious misinterpretation of the contents of the phenomena of life: the nations, being natural social and ethnic communities, are identified with a political institution of these communities - with the States (Achkasov, 2014; Mutagirov, 2014). As the most compelling argument against those who are oppose to such approach, they refer to the United Nations, consisting only of the States.

Due to the fault of the leading States of the 1930-ies, the largest nations of the world proved to be involved in the intense rivalry, and then in the fierce war between them. A possibility of excluding of such tragedies recurrence and ensuring peace and security in the world were seen in unification of all peoples on the principles of peace and cooperation, as well as compliance with certain general agreements. The idea of 'the establishment of a broad and permanent system of General Security' (Feis 1967: 21; Churchill 1952: vol. V, p. 442) were proclaimed in the Atlantic Charter, signed by the US President Roosevelt and British Prime-Minister Churchill in August 1941, and repeated in the Declaration of the United Nations on January 1, 1942 
(Declaration 1942). The tusk to define its contours was entrusted to the foreign ministries of Britain, the USSR and the United States; they substituted the concept of 'nation' for 'State' as though the word 'nation' was kept. Declaration of the Conference of Foreign Affairs Ministers of the USSR, United States and United Kingdom on October 30, 1943, also signed by Chinese Ambassador in the Soviet Union, said about necessity to creation "at the earliest practicable date a general international organization for maintaining international peace and security based on the principle of the sovereign equality of all peace-loving States and open to membership for all such States, large and small" (Moscow 1984, c. 192 - 193). Further discussions on this very important for the humankind's fate problems had been continued in a sense of the organization of the States, although the name remained unchangeable. As a result, the UN became an organization of the States; hundreds of the world's ethnicities and nations without their statehood are not represented in it. Some of them had formed the Unrepresented Nations and Peoples Organization.

Universal Organization for peace, security and cooperation should bring together the maximum number of the world's peoples with all their institutions (economic, social, political, cultural, etc.), for joint elaboration of a global strategy. Accordingly, the governing bodies of such organization should have as would many chambers structure, each of which has to resolve the problems of its scope. In the meantime, the UN serves as an illogical 'leviathans' association' or a 'cohort of Beelzebub', filling the world politics and international relations with the evil spirit. As the American geopolitics Nicholas Spykman believed, "the search for power is not made for the achievement of moral values; moral values are used to facilitate the attainment of power" [Spykman 1942: 18]. He was seconded by his compatriot and diplomat G. Kennan, arguing that "Morality as the general criterion for defining the conduct of States and, above all, as a yardstick to measure and compare the behavior of various States is not valid. Other criteria and sadder, more limited and more practical is allowed to prevail here" [Kennan 1952: 49]. H. Morgenthau maintained the same view, arguing that "States in anarchy cannot afford to be moral. The possibility of moral behavior rests upon the existence of an effective government that can deter and punish illegal actions' [Art 1983: 6].

In fact, all human values, the moral of which always determine the content and impact of all the rest, must become governing guidelines for true global institution for peace and security and for all of its members. Only in this case, the expectations of the peoples and practical results of the institute's activity will correspond to each other.

\section{NARROWNESS OF THE UN FOUNDATION AND ITS INCONSISTENCY WITH THE TUSKS OF THE TWENTY-FIRST CENTURY}

The next consideration in justification of the UN radical reforms necessity is a narrowness and inadequacy of its foundation to the greatness of the universal institution's building: it had been created in a totally different situation taking into account the very different tasks than those humankind has to solve today. Designing the contours of the future universal organization for peace and security in Tehran on November 29, 1943, the United States President Roosevelt said that it should be based on the principles of the United Nations, have no military matters and be unlike the failed League of Nations. The new organization should have no other power except advising, he believed. The President of the United States proposed to establish in its structure a 'police Committee', consisting of only 4 countries: The Soviet Union, the United States, the Great Britain and China, with the task to monitor the preservation of peace and prevent any new aggressions from Germany and Japan (Tehran 1984, pp. 102-103). The leaders of Britain and the USSR agreed in general with the President of the United States. 
The UN was established, therefore, as an institution, places and roles of the States in which have been laid down in accordance with their real contribution to the defeat of the 'Axis' countries in the Second World War. This had influenced, in particular, on the United Nations governing bodies structure, their functions and powers. In the conditions of the end of the world war it was to some extent understandable. The USSR, England and the United States played decisive role in the defeat of the common enemy of humankind. The UN was created as a tool for maintaining and consolidating the spirit of the nations united for a common purpose under the leadership of these three countries to which later China and unknown for what merits France were joined 1 . "Full consent of the great powers is essential to maintaining a lasting peace", a resolution of the Yalta conference of the 'Big Three' in February 1945 proclaimed, and only those powers had necessary force to maintain it. "In recognition of their special responsibility, a proposed voting procedure requires unanimity of the permanent members... on all the most important decisions related to the prevention of war, including all economic and military coercive measures " [Crimean 1984: 217 - 218].

Therefore, the mission of an associated manager was given simultaneously five large countries, though each of them pursued their own goals. Hence the right of each of the five States to absolute veto, the emergency powers of the 'Associated director' and the role of the 'Chorus', reserved for all other States.

Situation in the world and the relationships between countries had changed almost immediately after the start of the UN's activity. New generations of people had grown and the political map of the world radically changed for decades after the Second World War. Germany and Japan transformed from aggressors' and sources of threats to the peace into relative peace-loving and democratic States. 'Police' functions assigned to the winners, in new circumstances are no more justified; moreover, they harm the cause of peace and security on the Earth. These powers, turning the UN to a field of rivalry among themselves and one of the fronts of the cold war, become often the main culprits of instability and military conflicts in the world.

If 'leadership' resulted in promoting of peace and democracy, overcoming of the underdevelopment, poverty, ignorance and disease on the Earth, it should be welcomed and supported. But since it consists of diktat and threats for the peoples, wishing to preserve their identity and independence, as well of violation of fundamental norms of international law and human morality, it is fraught with danger.

\section{INCORRECT DISTRIBUTION OF POWERS BETWEEN GOVERNING BODIES OF THE UNITED NATIONS}

The absolute majority of the world's peoples did not participate in determining the contours and powers of this institution. The "Big Three", full of contradictions, jealousy and rivalry between them, had defined the architecture of the organization and mandates of its decisionmaking bodies. If the peoples of the world are considered the principal actors of the Organization, they all collectively ought to execute simultaneously the roles of a scheduler, conductor, and executive director of the entrusted to it mission. All decisions should be taken collectively in accordance with the principle of constitutional majority, after which they must become binding for all members of the international community. The positive experience of the

\footnotetext{
1 The Government of France capitulated almost immediately before Germany and collaborated with in the war against the countries of the anti-Hitler coalition somehow received status of the permanent member of the Security Council, while Mexico and then still dependent from Britain India, made significantly larger contribution to the victory over fascism, have not received it.
} 
international institutions of a special competence, whose strategy is determined with participation of all their structures, including non-governmental, could be useful here.

It is unfair and inconsistent with the principles of constitutionalism, that the collective will of the peoples of the world, expressed in the General Assembly, has only recommendatory character, while the resolutions of the organ composed of representatives only of fifteen States, five of which are permanent and with veto power, are considered as obligatory for all. Indeed, the decisive role in determining the fate of the entire world a body, consisting of less than seven per cent of its States, cannot be considered reasonable.

At Dumbarton-Oaks, where the UN Charter's draft was elaborated, the right of the permanent members of the Security Council to veto was not challenged; there was a controversy only about how to be in cases when permanent member of the Security Council becomes a party to the conflict, and should it vote on this issue? (Dumbarton Oaks Conference 1984). But at the Constitutional conference in San Francisco the statuses of the General Assembly and the Security Council, as well as the right of the five permanent members to veto, were strongly criticized. Representatives of many countries rightly noticed that the General Assembly of all Member States should become the main body of the UN with the right to making decisions obligatory for all its members, and delegate to the Security Council the right to make decisions only on issues related to sanctions. However, the delegations of the States established for themselves a special status in the Security Council, vehemently disagreed with this (see: Conference, 1980). They insisted that the General Assembly may discuss any question posed by any State or group of States, but its decisions should not be binding, and only the Security Council should have the power to adopt binding decisions with the consent of all its permanent members.

Any advancement and improvement are achieved, using the positive experience of previous generations and abandoning all negative in it. Indeed, there are much positive in the experience of the United Nations. The Charter of the United Nations and the "Declaration on principles of international law concerning friendly relations and cooperation among States in accordance with the Charter of the United Nations" had determined standards of the relationship between nations and their States. The UN contribution is great in elaboration and adoption of international agreements on human and peoples ' rights, norms of international law in various spheres of human life, etc. But, they contain, as wormholes, serious contradictions and ambiguities, not to mentioning that many of them are not observed at all.

The UN Charter says that the Organization is based on sovereign equality of all its members. It sounds well, but it is not true. In fact, some of the United Nations members are 'more equal' than others. Each of the five permanent members of the Security Council has more rights than all rest Member States together, and its veto results their common will in nothing. They established the rules according to which some States are prohibited from owning what themselves have long ago. The permanent members of the Security Council are not only more developed, rich, influential in the world, but also have all kinds of up to days' weapons, including nuclear missiles. Others are still poor and weak to protect their national security. But they are denied the right to strengthen their security from threats from the outside, and to create adequate weapon. Many UN decisions with efforts of the permanent members of the Security Council are aimed at preservation and perpetuation of this inequality.

The principle of the sovereign equality of States means that all permissions and prohibitions, including a production, distribution and use of the nuclear, chemical, biological and other weapons equally apply to all 'equal' under the Charter members of the international 
community. Who already had it by the time of the signing of the agreement on the ban, ought to stop any further work for the improvement of these weapons and to seek responsibly to conservation of the existing. It could be even better and fairer, if such a weapon would be destroyed without any harm to the environment.

Meanwhile, the permanent members of the Security Council, being the first nuclear weapon holders, swinging them and threatening those who do not have it, themselves incite them to contra-actions. Thus, the United States loudly declared in April 2002, that they began work on new nuclear warheads, with an aim to their application for destructing of highly protected underground structures. At the same time, the Pentagon has developed a strategy involving the use of nuclear weapons against any country, 'threatening the United States', including those who does not have nuclear-weapon. In November 2002, representatives of the United States and Britain's armed forces met in London, during which they discussed issues of the so-called 'no deadly weapons'. They discussed the possibility of applying such weapons as laser, able to blind enemy's manpower, as well as directional microwave radiation by which the enemy soldiers would be 'cooked' alive just as products are prepared in a microwave oven [United States and United Kingdom 2002].

On November 4, 2003 the President of the Russian Federation in an interview with Italian journalists also said that Russia had been forced to improve its nuclear weapons, but exclusively for the defense of the country. During the President's address to the Federal Assembly on March 1, 2018 new missile and nuclear technologies, "having no analogue in the world" were shown. Provoked by these statements, the United States tested even more sophisticated nuclear and missile weapons. It seems logical. But other peoples of the world are entitled with the right to the same remedies. However, the 'great powers' require from other countries, which they constantly threaten, not to produce weapons of mass destruction and not be equal with them.

Information about new types of deadly weapons from countries which the leaders of some States arrogantly called 'rogue', surely would have raised a stir in the rest of the world, and would be considered as evidence of the deadly threat to humankind. But the powerful States believe that they are allowed to do everything. "We do not want Iran had nuclear weapons, President Bush said at a joint press conference with Russian President Vladimir Putin in New York in September 2005, during the commemorative session of the UN General Assembly. Why Russia, United States and other big powers are allowed to have nuclear weapons, but 'equal' with them on international law countries not allowed to? Whether non-nuclear countries wish that the lager powers had nuclear weapons and constantly threatened them, none of the presidents had asked. That shows the double standards in the United Nations, which weaken it. Manifesting the utmost intransigence to countries without nuclear weapons, the UN through fingers looks at the 'pranks' of its more influential members, although it is clear that not the limited number of weapons of the 'rogue' countries, but huge arsenals of the permanent members of the Security Council create the greatest threat to peace and security in the world. The authors of the UN human development 2005 report, who defined such policies as "enlightened gain', were absolutely right (human development 2005).

\section{NORMS OF INTERNATIONAL LAW NEGATING EACH OTHER}

Low effectiveness of the UN also has been depended from its Charter and, consequently, international law, where exist mutually exclusive each other standards. First of all, these are, at first glance, reasonable rules and principles, as territorial integrity of the States, inviolability of their borders, non-interference in each other's internal affairs and the right of the nations to self-determination. 
Many of the modern States were formed long ago in the middle ages and had been expanded by violent accession of neighboring peoples, which were originally considered 'tributaries', then subjects and only in the second half of the 20th century all nations were entitled to the right to self-determination, up to formation of their own States. Naturally, as a result of the implementation of this right by peoples belonging to the multinational States yet, will 'broke' both their territorial integrity and borders, and this should be taken as inevitable (Mutagirov, 2018).

Much later had been recognized the principle of solidarity of all the States in ensuring effective protection of human and peoples' rights throughout the world. According to it, "human right... are no longer a matter only of the domestic jurisdiction of States. All matters relating to human rights, form the subject of international concern and, accordingly, the expression of concern by States on this subject never represents interference in the internal affairs of other States (Yearbook 1990: vol. 63-11, p. 338; The Resolution 1990).

Thus, contemporary international law allows interference in the internal affairs of States in cases when the human and peoples ' rights are flagrantly violated in them. That there was no conflict between the earlier and later norms of international law, it is necessary to clarify and refine their content with the recognition of the new standards.

\section{CONCLUSIONS}

The main causes of ineffectiveness of the UN are the narrowness of the foundation of the Institute, inconsistence of the purposes for which it had been established with the requirements of the late 20th and early 21 st centuries, unnatural distribution of competences between its governing bodies, inequality of its Member-States, contradictions between provisions of its Charter and the reality, etc. The pace of human progress accelerates and the world itself undergoes constant changes. The circle of the participants in international relations, as well as the areas of cooperation of peoples, and thus of the time requirements and ways to resolve them become wider. All this should be considered in the activities of the International Organization for peace, security and cooperation between different peoples of the world. It should function as advisory Tribune and fair arbitration Committee of all concerned peoples. Discussion and decision on all vital for humankind issues should take place at the general meeting or Supreme Council of the democratically elected representatives of the world's peoples by 'law of constitutional majority' (two-thirds or three-fourths of the members of the institute) with obligatory for all them force. Issues of each planetary sphere's life should be discussed in corresponding institutions (economic, political, spiritual, etc.)

There should have no place for the "police committee of the States" in the context of the twenty-first century, especially if a role of the Police is executed by 'Leviathans' or 'the robber brothers'.

The Security Council with limited functions would become a subsidiary body of the General Assembly, developing draft decisions on international security issues to be considered by the General Assembly, or serve as a Bureau of the General Assembly with the mandate to lead the UN activities in the period between its sessions. If keep some of its current functions, it is desirable, firstly, that the Security Council was formed solely from neutral countries, which would enhance the credibility, as well as the weight and influence of a status of neutrality in the world, secondly, with strict observance of geographic distribution of all world's regions and, thirdly, without dividing its members to permanent and temporary, but by the rotation every two to three years. In this case, it is desirable that decisions were taken by consensus. 


\section{References}

Annuaire de 1'Institut de Droit international. - Vol. 63-11. 1990.

Achkasov V. A. Ethnopolitologiya. Mockwa, 2014 (In Russian). (Achkasov V. A. Ethnopolitology. Moscow, 2014).

Art, R. J. and Waltz, K. N. (1983): 'Technology, Strategy, and the Uses of Force', in R. J. Art and K. N. Waltz (eds), The Use of Force (Lanham).

Churchill W. S. The Second World War. Vol. V. London, 1952.

Declaration of the United Nations. January 1, 1942 URL: http://school-collection.edu.ru/catalog/res/dcb7086c97be-4116-9a77-69af066e6/ Date of access 25.10. 2015.

Eastern European leaders at UN urge stronger cooperation to tackle threats to global peace and stability. http://www.un.org/apps/news/story.asp?NewsID=52029 Date of access 25.10.2015.

Etzioni Amitai. From empire to community: A new approach to international relations. Palgrave Macmillan Ltd. 2004.

Feis Herbert. Churchill, Roosevelt, Stalin. The War they waged and the Peace they sought. A diplomatic History of World War II. New York, 1966.

Fassbinder B. UN Security Council Reform and the Right of Veto: A constitutional Perspective (Legal Aspects of International Organization. Vol. 32). London, 1998.

Jeffrey Sachs. After seventy: Why you need to change the UN? (www/project-syndicate.org Date of access 05.10.2015).

Kennan George F. Realities of American Foreign Policy. Boston: Little, Brown \& Company, 1977.

Latin American leaders urge reform of UN bodies, highlight 2030 'agenda of change'

http://www.un.org/apps/news/story.asp?NewsID=52033\#.VgpE-nrtlHw Date of access 29.09. 2015).

Morgenthau Hans J., Politics among Nations: The Struggle for Power and Peace, Fifth Edition, Revised, (New York: Alfred A. Knopf, 1948).

Mutagirov D Z. Istoriya i teoriya meshdunarodnyh otnosheniy. Meshdunarodnyie politicheskiie instituty. Urayt, 2018. (Mutagirov D. Z. (2018). History and theory of international relations. International political institutions. Moscow, Urite). (In Russian).

Mutagirov D Z (2014). Demokratiya kak universalnaya tsennost. Moskwa, Logos. (Mutagirov D. Z. Democracy as a universal value. Moscow, Logos, 2014). (In Russian).

Mutagirov D. Unequal status of equal peoples: Causes and ways to address the Problem / Advances in Social Sciences Research Journal - Vol.5, No.5. Pp. 53 - 63.

Report of the Secretary-General on the work of the Organization on 70-th session of the UN General Assembly. United Nations, New York, 2015. URL: http://www.un.org/ru/sg/speeches/reports/70/report.shtml Date of access 25.10. 2015.

Spykman Nicholas John. America's Strategy in World Politics - The United States and the Balance of Power. Transaction Publishers.1942.

The Charter of the United Nations. URL: http://www.un.org/en/charter-united-nations/index.html Date of access 07. 05. 2018.

The Conference of representatives of the three countries at Dumbarton Oaks (21 August-September 28, 1944). M., 1984. (In Russian)

The Crimean Conference of the leaders of the three allied powers - the USSR, the United States and the United Kingdom (28 November-December 1, 1943. A collection of documents. M., 1984, pp. 217-218.

The Moscow Conference of Ministers for Foreign Affairs of the USSR, the United States and Great Britain (19-October 30, 1943). M. 1984. (In Russian).

The Resolution "Human rights and the principle of non-interference in the internal affairs of States" adopted by the Institute of international law (Spain, Santiago de Compostela,1990.

The South African President calls for reform of Security Council. URL: http://www.un.org/apps/news/story.asp?NewsID=52021 Date of access 25.10.2015.

The Tehran Conference of the leaders of the three allied powers - the USSR, the United States and the United Kingdom (28 November-December 1, 1943. A collection of documents. M., 1984). (In Russian). 
The United Nations Conference in San Francisco (25 April - June 26, 1945).

M., 1980.710 p.). (In Russian).

The UN human development report 2005. URL : http://stone.undp.org/hdr/presskit/ Date of access 22.10.2015.

The UN News 2015.

URL: http://www.un.org/apps/news/story.asp?NewsID=52021.

The United States and the United Kingdom are developing a new "non-lethal" weapons. URL:

http://lenta.ru/world/2002/11/03/weapon/ Date of access 03.11. 2015. 